\title{
Lampião da Esquina na mira da ditadura hetero-militar de $1964^{*}$
}

\author{
Renan Quinalha**
}

\section{Resumo}

No presente artigo, o intuito é examinar, a partir de registros históricos, imprensa da época e acervos de documentação oficial, os diferentes modos como a ditadura hetero-militar de 1964 tentou afetar, direta ou indiretamente, o jornal "Lampião da Esquina" e seus editores. Além das medidas repressivas, pretende-se também analisar as formas de reação e de resistência que foram agenciadas, permitindo uma melhor compreensão das causas exógenas e endógenas que levaram ao fim do jornal em 1981.

Palavras-chave: Ditadura, Repressão, Imprensa Gay, Lampião Da Esquina.

* Recebido em 06 de junho de 2019, aceito em 16 de junho de 2020.

** Professor de Direito da Unifesp (Universidade Federal de São Paulo), São Paulo, SP, Brasil. renanhq@gmail.com / https://orcid.org/0000-0002-8467-1877 
The Newspaper Lampião da Esquina in the Sights of the Hetero-Military Dictatorship of 1964

\begin{abstract}
The purpose of this article is to use the press of the time and archives of official documents, to examine the different ways in which the hetero-military dictatorship imposed in 1964 sought to directly or indirectlypressure the newspaper "Lampião da Esquina" and its publishers. Besides the repressive measures, it also analyzes the forms of reaction and resistance that were undertaken, allowing a better understanding of the exogenous and endogenous causes that led to the newspaper's demise in 1981.
\end{abstract}

Keywords: Dictatorship, Repression, Gay Press, Lampião Da Esquina. 
Em 30 de agosto de 1977, o jornal Folha de São Paulo publicou nota chamando a atenção para a iminente chegada de Winston Leyland ao Brasil. Intitulada "O rei do gay power vem aí", a pequena matéria iniciava conclamando os homossexuais brasileiros com a seguinte mensagem:"Atenção poetas-namorados, correi, voai, saltitai: é chegada a hora de dar bandeira em São Francisco, o paraíso. Escrevam, escrevam muitos poemas, porque vem aí o diretor da revista Gay Sunshine (...)".

De fato, em outubro de 1977, Leyland, editor do mais importante periódico literário do movimento homossexual dos EUA, fundado em São Francisco e contando então com mais de 30 mil leitores, visitou o Brasil por mais de um mês, percorrendo diversas capitais. Desde 1971, ele já dirigia esse jornal trimestral, que tinha a colaboração de escritores gays célebres, como Tennessee Williams, Gore Vidal, Allen Ginsberg e Jean Genet.

Hospedado inicialmente no Rio pelo advogado João Antônio Mascarenhas, o "papa da homossexualidade", como alguns o apelidavam, veio ao país para aprofundar sua pesquisa sobre literatura e arte na América Latina, com um enfoque na sexualidade.

Nesse momento, o Brasil ensaiava os primeiros e ainda tímidos passos de um lento e gradual processo de liberalização política. Homossexuais se faziam mais presentes nas grandes cidades $e$ surgia, em diversos veículos da imprensa, uma curiosidade crescente em torno dessas pessoas que desafiavam as normas de comportamento padrão de gênero e de sexualidade. Toda essa efervescência, contudo, convivia com diversas formas de repressão moral de uma ditadura heteromilitar (Quinalha, 2017).

Mal sabia Leyland que sua visita ao Brasil teria o efeito de catalisar a vontade ainda incipiente - e bastante dispersa - de diversos intelectuais e ativistas no sentido de organizar uma publicação voltada especificamente para o público homossexual.

Com efeito, o grupo de jornalistas homossexuais assumidos que se articulou inicialmente em torno de Mascarenhas, com o objetivo primeiro de entrevistar Leyland para uma matéria no Pasquim, acabou dando o pontapé inicial no projeto de uma publicação feita por homossexuais e voltada para os grupos minoritários: o Lampião da Esquina.

À frente da iniciativa, estavam figuras importantes da cena cultural carioca e paulista, além de intelectuais de prestígio, ainda que jovens. Personagens que despontavam na universidade, no jornalismo e nas letras: os jornalistas Adão Costa, Aguinaldo Silva, Antônio Chrysóstomo, Clóvis Marques, Francisco Bittencourt, Gasparino Damata e João Antônio Mascarenhas; o artista plástico Darcy Penteado; o crítico de cinema Jean-Claude Bernardet; o escritor João Silvério Trevisan e o antropólogo Peter Fry.

Esse grupo foi ampliado com a entrada de outros interessados e, para financiar o jornal, nove dos onze idealizadores cotizaram para criar uma editora. Além disso, fizeram uma campanha de arrecadação, mandando cartas para 12 mil amigos e amigos dos amigos homossexuais de todo o Brasil. Conforme relata MacRae, a recepção foi muito boa e o montante arrecadado financiou os dois primeiros números do jornal, que tinha formato de tabloide, com 20 páginas e uma tiragem mensal que oscilava entre 10 e 15 mil impressos (Macrae, 1990:72). A entrevista com Leyland seria publicada justamente neste novo jornal, mas apenas em seu número 2, de julho de 1978.

Em abril de 1978, a edição experimental número zero fora lançada ao público, circulando mensal e ininterruptamente até junho de 1981, perfazendo um total de 37 edições em pouco mais de 3 anos de existência.

O número zero do jornal estreou com um editorial convidativo e, ao mesmo tempo, provocador, revelando de partida uma proposta sofisticada. Com o título "Saindo do gueto", o texto começava com um diagnóstico de conjuntura elaborado, avaliando as potencialidades e limites da "abertura" então em curso no país. "Brasil, março de 1978. Ventos favoráveis sopram no rumo de uma certa liberalização do quadro nacional [...] Mas um jornal homossexual, para quê?" (Lampião da Esquina, 1(0), 1978:2), assim começa o texto de abertura do jornal.

Essa pergunta central seria uma presença constante na trajetória do "Lampião". O que era "ser homossexual" naquele momento? Qual o sentido de uma publicação voltada particularmente para um público marcado pela referida identidade em construção? 
A resposta dada coletivamente no ato fundador, contudo, era bastante clara e contundente. Contra a "resposta mais fácil" de "assumir" a cartilha já definida por uma "Grande Consciência Homossexual", era antes preciso "dizer não ao gueto e, em consequência, sair dele", uma vez que "o que [lhes] interessa[va] [era] destruir a imagem padrão que se faz[ia] do homossexual, segundo a qual ele [era] um ser que viv[ia] nas sombras, que prefer[ia] a noite, que encara[va] a sua preferência sexual, como uma espécie de maldição" (Lampião da Esquina, 1 (0), 1978:2).

Questionava-se, assim, a existência de uma única identidade homossexual confinada nos guetos e estigmatizada pela associação recorrente com o submundo da criminalidade, da corrupção moral e das drogas.

Caracterizando os homossexuais como uma "minoria oprimida" que "precisa de voz", a proposta do jornal politizava a condição e inovava ao postular:

Lampião reivindica em nome dessa minoria não apenas se assumir e ser aceito - o que nós queremos é resgatar essa condição que todas as sociedades construídas em bases machistas lhes negou: o fato de que os homossexuais são seres humanos e que, portanto, têm todo o direito de lutar por sua plena realização, enquanto tal (Lampião da Esquina, 1 (0), 1978:2).

No presente artigo, por meio da análise de acervos documentais, fontes da imprensa e relatos dos protagonistas da história em tela, serão examinados os distintos modos pelos quais a ditadura afetou o jornal Lampião da Esquina e seus editores. De um lado, será possível notar que o regime repressivo atuou de maneira direta, por meio de investidas autoritárias no sentido de vigiar, produzir informações e dossiês, realizar devassa contábil, tudo com o objetivo de restringir a circulação e o alcance do periódico; por outro, houve também certa influência indireta do regime, provocando órgãos policiais e ministério público para processar os editores, reforçando uma cultura de medo que contribuiu, de forma significativa, para acentuar as dificuldades já encontradas para um pequeno jornal da imprensa alternativa em contexto de autoritarismo político com forte acento de conservadorismo moral.

No entanto, além da dimensão repressiva, pretende-se também examinar as formas de resistência, agenciamento de apoios e negociações que marcaram a defesa do jornal diante da atuação ditatorial. Desse modo, será possível iluminar tanto o debate emergente em recentes reflexões acadêmicas sobre as complexas relações entre a ditadura e as sexualidades dissidentes, quanto as razões endógenas e exógenas que contribuíram para o fim do jornal, considerado até hoje como a mais impactante publicação da imprensa gay brasileira.

\section{Lampião sob vigilância: "a propaganda do homossexualismo"1}

Apesar dos pesares, o jornal que marcou toda uma geração de gays que começavam a viver fora do armário, com todas as adversidades que isso implicava em um momento de conservadorismo acentuado, não passaria despercebido aos olhos atentos da ditadura. Foram diversas as modalidades de violência e repressão que atingiram o Lampião e seus editores. A espionagem oficial esteve atenta para o risco que ele representava, sobretudo à moral e aos costumes, desde a primeira hora de seu funcionamento.

Documento produzido pelo Centro de Informações do Exército (CIE), em 6 de abril de 1978, anunciava a preocupação com o lançamento do jornal, materializada já no assunto do comunicado: "Imprensa gay - 'Lampião'". Endereçado a outras agências de vigilância - mais especificamente Agência Central do Serviço Nacional de Informações (AC/SNI); Centro de Informações da Aeronáutica (CISA); Centro de Informações da Marinha (CENIMAR); e Divisão de Segurança e Informações do Ministério da Justiça (DSI/MJ) - o documento apontava que as notícias do iminente lançamento do jornal "permite antever a circulação dirigida de mais uma publicação que abrangerá

\footnotetext{
1 "Homossexualismo" era a palavra comumente utilizada pelos órgãos de repressão e vigilância da ditadura para se referir às práticas e identidades homossexuais. Originada no campo médico-científico, essa expressão, marcada pelo sufixo "ismo", mantinha certa associação à ideia de uma doença ou transtorno. Para afastar essa patologização, já na época retratada neste artigo, preferia-se usar o termo "homossexualidade", tido como mais neutro e como o contraponto da heterossexualidade.
} 
temas atentatórios à moral e contestatórios à ordem e ao regime" por defender "homossexuais como atividade normal" além de outros "setores marginalizados da sociedade".

Prosseguia o relatório destacando que "é notado um esquema de apoio à atividade dos homossexuais", apoio esse "baseado, em sua quase totalidade, em órgãos de imprensa sabidamente controlados por esquerdistas", podendo-se estimar o alto interesse comunista no proselitismo em favor do tema". Arrematava o documento que causa estranheza por não haver restrição à circulação dessa notícia sobre o Lampião. Afinal, "quando estão em jogo preceitos morais e éticos que são o sustentáculo da família brasileira, principal célula de resistência ao avanço de ideologias espúrias", devendo-se coibir o "uso exagerado dessa liberdade" (Brasil, 1978a).

Como 1978 era também um ano eleitoral que testemunharia a crise de legitimidade da ditadura nas urnas, o documento da Divisão de Segurança Institucional do Ministério da Justiça, Informação n. 895/78, difundida para o gabinete e de caráter sigiloso, indicava preocupação com a possibilidade dos temas da "liberdade do homossexualismo" e da "legalização do aborto serem pautados nas eleições", que seriam realizadas naquele mesmo ano (Brasil, 1978b).

Nota-se que, a despeito das poucas chances de vitória eleitoral, o sistema de informação do regime preocupou-se em levar o assunto até o gabinete do Ministro da Justiça, pois o Lampião havia destacado a ausência de candidatos claramente defensores dos direitos dos homossexuais, assim afirmando:

O periódico 'LAMPIÃO DE ESQUINA', publicado pela 'Esquina Editora de Livros, Jornais e Revistas Ltda', do RIO DE JANEIRO/RJ, órgão da imprensa 'nanica' que se dedica à promoção do homossexualismo, em sua edição n. 6, de Nov78, publicou, na página 4, os artigos intitulados 'E NO DIA 15, A BONECA MORRE AFOGADA?', de DARCY PENTEADO, e 'UM CANDIDATO FALA MAIS ALTO', de AGUINALDO SILVA (Brasil, 1978b, destaques no original).

Este último texto era, na verdade, de Baiardo de Andrade Lima, candidato em 1978 a Deputado Federal pelo MDB de Pernambuco e único político que incluía expressamente a "liberdade do homossexualismo" entre suas promessas. Vale ressaltar que se trata do primeiro candidato a incluir tal agenda em sua plataforma de campanha, um tema que só apareceria mais durante campanhas eleitorais do começo dos anos 80.

Outros órgãos de informação expressaram a mesma preocupação em relação à postura do jornal. A Apreciação Especial n.001/19/AC/79, enviada da AC/SNI ao Ministro da Justiça, trazia em anexo um relatório com o assunto "atuação dos órgãos de comunicação social - retrospecto do $2^{\circ}$ semestre de 1978 - perspectivas para 1979". Um dos itens destacados nesse balanço pontuava, especificamente, a "propaganda sobre o homossexualismo" que estaria sendo "divulgada, particularmente, através do periódico Lampião da Esquina" (Brasil, 1979a).

O Lampião tocava em temas delicados, merecendo uma preocupação constante por parte dos órgãos de informação que faziam o monitoramento da imprensa. Isso porque, como já mencionado ao longo deste trabalho, para além de criticar politicamente o regime, o jornal trazia uma proposta nova de integrar-se às lutas democráticas com uma agenda de minorias marginalizadas, até então, dentro do próprio campo oposicionista. O documento do Ministério da Aeronáutica, Informação n. 0854/CISA-RJ, difundido para os demais órgãos de informação, destacava a entrevista do intelectual e militante negro Abdias Nascimento para o jornal, na qual ele afirmava que "mulheres, negros, índios, homossexuais, dev[iam] lutar juntos contra a repressão" (Brasil, 1980a), o que logo despertou a atenção da ditadura.

Outras formas de monitoramento e de sanção eram planejadas também pelos órgãos repressivos, como a recomendação dos órgãos de informação para o governo federal boicotar qualquer publicidade governamental no jornal, considerado parte da "imprensa contestatória". A Informação n. 051/19/AC/80, proveniente da AC/SNI, por exemplo,

não recomenda a difusão de anúncios de propaganda por entidades da Administração Pública Federal, em face da prevalência nesses veículos da divulgação de temas hostis ao Governo Federal, como também, em alguns casos, da abordagem de assuntos atentatórios à moral e aos bons costumes". Logo em seguida, constava o Lampião da Esquina, descrito como "periódico 
da imprensa 'nanica" que "defende o homossexualismo e aborda assuntos atentatórios à moral e aos bons costumes (Brasil, 1980b)

Em 1981, a diretriz foi reafirmada pela Informação n. 202/04/DSI/MJ/346778, de 26 de junho de 1981, na qual a Agência Central selecionou "os principais órgãos da imprensa (jornais e revistas) em que, considerando sua linha de atuação, não se recomenda[va] a difusão de publicidade, anúncios e atos oficiais", tendo sido o Lampião descrito como "mensário que defende o liberalismo [sic] sexual e faz propaganda do homossexualismo" (Brasil, 1981).

Mas o pior não foi esse boicote econômico por parte das entidades da Administração Pública que pouco afetaria um jornal que já nascera independente, apesar das suas dificuldades econômicas. Diante da ineficácia dessas medidas de boicote e da insistência dos órgãos de informação em chamar a atenção para o Lampião, a repressão passou a ocorrer de outras maneiras menos sutis.

\section{“Ofensa à moral e ao pudor público": o inquérito 25/78}

No artigo publicado no Lampião, com o título "Uma capa com muitas estrelas", que não foi assinado individualmente por nenhum dos membros do Conselho do jornal, muito provavelmente para evitar ainda mais exposição, os lampiônicos denunciaram a perseguição mais sistemática que começaram a sofrer no início de 1979, por iniciativa dos órgãos de segurança.

No ano anterior, Aguinaldo já havia sido convocado a prestar depoimento quando o jornal tinha recém-completado seis meses de vida. Conforme registra seu termo de declarações perante o DOPS/SR/DPF/RJ, datado de 24 de novembro de 1978, ele tentava já se esquivar da censura, destacando sua trajetória e outras experiências profissionais ao afirmar ser jornalista há mais de 17 anos, contando com trabalho fixo na Rede Globo e mais de 10 livros publicados de sua autoria. Aguinaldo asseverou que todos os textos eram aprovados pelos conselheiros em suas reuniões mensais, e "que todo o Conselho Editorial do jornal Lampião da Esquina é composto dessa minoria da sociedade, de homossexuais" (Brasil, 1978c). O grifo no original do documento indicava como a orientação sexual dos editores era uma informação considerada relevante para os investigadores.

$\mathrm{O}$ jornalista mostrou-se, ainda, bastante didático ao, aparentemente, tentar aliviar a repressão e despistar uma associação exclusiva do jornal com a homossexualidade, sustentando que "o objetivo fundamental da criação do Lampião da Esquina [era] dar divulgação a matérias de modo geral, e também divulgar notícias sobre uma minoria, que [assim] é considerada perante a sociedade. Ou seja, os "Homossexuais", que "muito embora inicialmente est[ivessem] predominando sobre matérias referentes ao homossexualismo, dever[ia] modificar sua forma, para dar voz a uma outra minoria". Ademais, "os artigos escritos pelo declarante não [vinham a] ferir a moral e os bons costumes"(Brasil, 1978c).

Apesar de não adotar uma postura de afronta, Aguinaldo não escondia que o jornal pretendia desvincular a homossexualidade da estigmatização que lhe era geralmente imputada pela imprensa, até porque isso já tinha ficado bastante claro nas primeiras seis edições:

até a fundação do jornal Lampião da Esquina, sempre houve dificuldade para uma publicação limpa sobre o homossexualismo, vez que outros jornais quando fazem referências ao homossexualismo, o fazem de maneira preconceituosa, ligando o homossexualismo a criminalidade (Brasil, 1978c).

Não há registro de que o depoimento tenha avançado naquele momento, mas isso não tardaria a acontecer, como se nota em outros documentos disponíveis.

O parecer n. 3348, por exemplo, datado de 22 de dezembro de 1978 e assinado pela técnica de censura Marina de A. Brum Duarte, no âmbito do mesmo inquérito policial 25/78 - DOPS, sentenciava que os artigos constantes dos dois primeiros números do jornal Lampião

enquadra[vam]-se na medicina psicológica e part[iam], sem dúvida, de personalidades com problemas comportamentais de natureza sexual, que se configura[vam] nas fronteiras 
psicológica e judicial e fer[iam] os preconceitos da moral e bons costumes de nossa sociedade heterossexual - (Lei censória e seus artigos) 20.493/46 em seu regulamento (Brasil, 1978d).

A censora ainda acrescentava que "essas atitudes públicas [vinham] crescendo precisamente pela liberalidade licenciosa reinante (heterossexual) de revistas, bailes (enxutos), programas (novelas), etc. Que coloca[vam] concomitantemente o homossexualismo na pretensão de se afirmar e concorrer de igual para igual". Em suas palavras, "tudo isso ocorr[ia] pela amoralidade crescente da sociedade contraditória e violenta, cujos problemas se avoluma[vam] cada dia que passa" (Brasil, 1978d). Assim, a censora opinava pelo veto do periódico e de sua circulação. O parecer consultivo, bastante contundente e produzido por uma técnica "especializada" do aparato da censura, foi determinante para a continuidade do inquérito.

Diante da convocação para a identificação datiloscópica, Agnaldo Ferreira da Silva, Francisco Badaró Bittencourt Filho, Adão José Acosta, Clóvis Marques e Roosevelt Antonio Chrysostomo de Oliveira, todos jornalistas do "Lampião", impetraram o Habeas Corpus n. 4.992 contra o Delegado Chefe da DOPS/SR/DPF/RJ, alegando coação indevida por parte dessa autoridade. O juiz federal Ariosto de Rezende Rocha, do Rio de Janeiro, em 25 de janeiro de 1979, oficiou referida autoridade para prestar esclarecimentos sobre a alegada coação até o dia 26 de janeiro às $14 \mathrm{~h}$.

Em sua resposta, o Delegado de Polícia Federal William Barth alegou que os impetrantes feriram a Lei de Imprensa por ofensa à moral e aos bons costumes, levando à instalação do Inquérito Policial n. 25/78. Depois de receber o parecer censório acima referido, a autoridade argumentou que era impositivo o indiciamento dos impetrantes. A despeito de terem comparecido no dia 23 na Delegacia para ratificar os depoimentos, os impetrantes, "todavia, na hora da identificação datiloscópica, se furtaram a cumprir a formalidade legal, através da ingerência de seus advogados" (Brasil, 1979b). Alegou, por fim, que esse tipo de identificação é uma formalidade padrão indispensável ao inquérito, não se constituindo em coação ilegal.

Apesar da tentativa de resistência, a investigação teve prosseguimento no dia 2 de abril de 1979. Cinco dos editores cariocas tiveram de comparecer à sede do Departamento de Polícia Federal, na Praça Mauá no Rio de Janeiro, para serem submetidos a procedimento de identificação criminal. Isso porque, dias antes, haviam sido já identificados os jornalistas Antônio Chrysóstomo, Francisco Bittencourt, Aguinaldo Silva, Clóvis Marques e Adão Acosta. Todos os cinco, membros do Conselho Editorial do Lampião e colaboradores regulares nas páginas do jornal, "foram fotografados de frente e de perfil (e não de costas, como se esperava) e tiveram suas impressões digitais tiradas dezenas de vezes" (Lampião da Esquina, 1 (11) 1979:3), conforme registra ironicamente o periódico, que estampou em sua capa a referida fotografia de todos eles trajando a camiseta listrada de presidiário e com uma placa pendurada no peito com a inscrição "1077" e a data de 2 de abril de 1979.

O número "1077" era uma referência ao decreto editado em 1970 para atualizar as regras da censura, no qual estavam todos sendo enquadrados pela acusação de "ofensa à moral e ao pudor público" segundo matéria do Lampião, além da aplicação da Lei de Imprensa destacada nos documentos da repressão. Apesar de apreensivos, os jornalistas mostravam-se bem-humorados no artigo de denúncia, reivindicando a imagem do Davi contra o Golias, gigante este que representaria a ditadura. Além disso, estavam confiantes, como transparecia na nota, pois as "absolvições recentes de Celso Cúri em São Paulo, e do poeta Nicolas Behr em Brasília, ambos enquadrados no mesmo item do decreto 1077 mostra qual é a posição da Justiça, a essa altura dos acontecimentos - e da vida nacional quanto a esse tipo de acusação" (Lampião da Esquina, 1 (11) 1979:3).

$\mathrm{O}$ artigo até poderia estar correto em apostar que o caso deveria ser arquivado. Ainda era cedo demais para que tal afirmação se verificasse na prática, contudo, pois o inquérito já havia sido instaurado.

Dias após os depoimentos no Rio de Janeiro, tinha já chegado a vez dos membros do Conselho Editorial residentes em São Paulo - Darcy Penteado, João Silvério Trevisan, Jean-Claude Bernadet e Peter Fry, que se livrou por estar em Fortaleza - prestarem depoimentos. Trevisan relatou a dificuldade que a polícia demonstrou, durante a oitiva de depoimentos, para compreender a existência de um jornal gay feito por "viados" que foram prestar depoimentos engravatados como homens e não travestidos de mulheres ou "desmunhecados": 
Eu me lembro que, quando chegamos na delegacia, em Higienópolis, o delegado fez o interrogatório errado. Ele confundiu o processo, achando que se tratava de um caso de subversão. Ele nos perguntava: 'Mas quando é que vocês foram para Cuba? O que vocês foram fazer lá?', e foi o escrivão que percebeu o equívoco... ele [o delegado] não estava entendendo nada (Péret, 2011:54).

Apesar dos equívocos, o procedimento seguiu seu curso normal e foi definitivamente instaurado. A apuração se arrastou durante mais de oito meses sem qualquer ato oficial, dando respaldo a essa pouco habitual extensão de prazo. Mesmo à época, o inquérito já tinha sua duração delimitada para não submeter o investigado ad aeternum ao ônus que advém da investigação criminal.

O relatório do Delegado de Polícia Federal e Chefe da DOPS/SR/DPF/RJ, Miguel de Lacerda Mendes, datado de 9 de agosto de 1978 e dirigido ao Coordenador Regional Policial Edyr Carvalho, apontou que o jornal

apresenta[va] matéria ofensiva à moral e aos bons costumes em suas notas e reportagens, vez que em suas mensagens [havia] um incentivo muito forte à prática do homossexualismo, sempre lastreado em nome de pessoas que conseguiram celebridade, fama e destaque junto à sociedade, devido suas atividades profissionais independentemente de suas preferências sexuais recaírem em parceiros do mesmo sexo, o que requer[ia] a aplicação das medidas em vigor para coibir tais abusos (Brasil, 1978e).

A preocupação central continuava sendo, assim, com a "propaganda", o "exibicionismo" e a "apologia" à homossexualidade como uma ameaça à família e aos valores morais conservadores.

O referido relatório registrava, ainda, que o fato de "não haver clandestinidade na circulação do jornal", o qual estava devidamente registrado no Cartório do Registro Civil de Pessoas Jurídicas da capital fluminense, "não exim[ia], até pelo contrário, lhe imp[unha] o dever de respeitar e cumprir as regras de direitos que caracteriza[vam] a política do govêrno na área da moral e dos bons costumes, expressas com absoluta clareza no texto da Lei n. 5250 (Lei de Imprensa)"(Brasil, 1978e).

Concluía-se o relatório examinando a linguagem utilizada pelo jornal, que "somente pelo aspecto gramatical pod[ia] ser considerada normal, posto que sob o ponto de vista moral [era] acintosamente grosseira, de uma realidade grotesca e chocante". Anexo ao documento, encontravam-se as duas primeiras edições do jornal, consideradas "suficientes" como "prova do desrespeito às regras do artigo 17 da Lei 5250", sendo que algumas das gravuras "[eram] audaciosas e obscenas, sem desprezar a licenciosidade dos títulos". Encerrava-se o relatório com requerimento de "instauração do competente IPL" (Brasil, 1978e).

A autoridade que recebeu este ofício logo despachou, em letras de mão, no próprio documento, o seu "de acordo. A DOPS para proceder na forma sugerida", despacho este de 15 de agosto de 1978(Brasil, 1978e). Seguindo esta determinação, consta Portaria sem numeração e datada de 21 de agosto de 1978, em que o Delegado de Polícia Federal e Chefe da DOPS/SR/DPF/RJ Miguel de Lacerda Mendes, com base na Portaria 359-B, do Ministério da Justiça, resolveu instaurar o inquérito policial. O objetivo era

a apuração do responsável ou responsáveis pela publicação, nos ns. 'ZERO' e 'UM' dos meses de 'Abril' e 'Maio', do Jornal 'LAMPIÃO DA ESQUINA', de matéria ofensiva à moral e aos bons costumes, vez que, em suas mensagens, [havia] um incentivo muito forte à prática do homossexualismo (Brasil, 1978f, grifos no original).

$\mathrm{O}$ inquérito, assim, parecia surtir mais efeito não se chegasse a um termo com o indiciamento dos responsáveis, mas sim se fosse perpetuado indefinidamente como uma releitura kafkaniana da persecução penal. O receio de que pudesse haver um revés no Poder Judiciário, que havia sofrido intervenções por parte da ditadura, mas se mostrava relativamente independente na aplicação da 
legislação ${ }^{2}$, pode ter levado os órgãos de investigação a manter o procedimento no âmbito administrativo, em que tinham total controle das fases e procedimentos. Contudo, cientes dos limites dessa estratégia, os mesmos órgãos atacariam logo em outras frentes.

\section{“Quem nos financia?”: a devassa nas contas do Lampião}

Diante da dificuldade em interromper a circulação do jornal pela censura direta, os órgãos de segurança desencadearam também uma devassa contábil. No dia 10 de julho de 1979, ao chegar na sede do jornal, um dos lampiônicos deparou-se com um envelope timbrado do Serviço Público Federal. Na carta oficial, constava uma solicitação do delegado responsável pelo IPL 25/78-DOPS que tramitava contra o jornal. O requerimento dizia:

a fim de instruir inquérito policial que ora tramita nesta Regional, solicitamos a V. Sa. se digne determinar providências no sentido de fazer apresentar nesta DOPS ... o Tesoureiro ou pessoa encarregada da contabilidade relativa à movimentação do jornal Lampião da Esquina, munido das respectivas escriturações ou balancetes relativos aos meses de janeiro a maio de 1979 (Brasil, 1979c).

A ditadura, nesse momento, lançava mão de uma investigação contábil baseada em uma ação administrativa e fiscal que, apesar de formalmente legal e aparentemente rotineira, era medida de perseguição política aos veículos considerados "subversivos". Uma perícia dessa natureza já havia sido feita com o jornal Versus em abril de 1979 e também culminaria, em 1981, na penhora de bens do Tribunal da Imprensa, por conta de débitos previdenciários (Kucinski, 2001:96).

A comunicação gerou apreensão, pois era imprevisível até que ponto a repressão poderia criar empecilhos para a o jornal, mas a solicitação não foi prontamente atendida. Consultado, Luís Celso Soares de Araújo, advogado da Associação Brasileira de Imprensa, ponderou que "a solicitação era ilegal e arbitrária, e deveria ser ignorada; mas, em nenhum momento deveríamos silenciar sobre isso: era preciso denunciar a arbitrariedade aos jornais" (Lampião da Esquina, 2(15), 1979:5).

Já em 11 de julho de 1979, dia seguinte à intimação, o Sindicato dos Jornalistas do Município do Rio de Janeiro enviou telegrama ao Ministro da Justiça solicitando providências quanto à devassa que era então realizada nas contas do "Lampião da Esquina". Afirmava a entidade sindical que estavam "animados com declaração de Sua Excelência, o Presidente, contra violência à sucursal mineira do Jornal Em Tempo", cuja sede havia sido atacada depois de ter publicado lista com nomes de 233 torturadores.

O Sindicato cobrava, no entanto, "providências para apuração de responsabilidade e também definição do governo contra exigências na verificação contábil do jornal 'O Lampião' por parte da polícia federal" (Brasil, 1979d). Assim, o requerimento apontava o descompasso existente entre um discurso mais liberalizante e uma prática ainda autoritária do governo. Vale observar que o Sindicato dos Jornalistas, controlado por forças da esquerda organizada, manifestou apoio decisivo ao Lampião, o que, no mínimo, relativiza o argumento de que todos os agrupamentos de esquerda não se importavam com as lutas dos homossexuais como se fossem algo menor e secundário.

Assim que o expediente chegou ao gabinete do Ministro da Justiça, ele foi analisado pelo assessor Jorge de Albuquerque e Melo, que propôs o encaminhamento ao DPF em 20 de agosto de 1979. Em 30 de agosto do mesmo ano, o chefe do DPF determinou à SR/RJ que informasse "quanto ao procedimento apuratório a propósito da publicação 'O Lampião". O expediente, após chegar ao órgão de destino, foi levado aos cuidados do Dr. Motta, em referência ao Delegado de

\footnotetext{
2 Neste momento de liberalização - ainda que limitada - da ditadura, nota-se que o Poder Judiciário proferiu algumas decisões que se tornaram precedentes importantes para restringir o alcance da censura moral. Nesse sentido, merecem destaque dois casos. O primeiro é o do jornalista Celso Curi, processado em 1976 por violação à "moral e aos bons costumes" por conta da sua Coluna do Meio no jornal Última Hora, voltada para homossexuais. Ele acabou perdendo seu emprego, mesmo tendo sido, posteriormente, absolvido na Justiça. O segundo foi o do poeta Nicolas Behr, processado em agosto de 1978 por "porte de material pornográfico", mas com denúncia rejeitada pelo juiz (Quinalha, 2017).
} 
Polícia Federal Bel. José da Silva Motta, então presidente do inquérito, em 10 de setembro de 1979.

A autoridade passou, então, a expor em seu relatório o andamento do procedimento e sua apreciação quanto ao tema. Segundo ele, o inquérito n. 25/78 foi instaurado

para apurar a responsabilidade criminal dos indivíduos que compõem o Conselho Editorial do jornal LAMPIÃO DE ESQUINA, autores de publicações de matéria ofensiva à moral $e$ aos bons costumes, em flagrante desrespeito às regras do artigo 17 da Lei 5.250, de 9 de fevereiro de 1967.

Sobre o pedido de vistas dos livros contábeis da editora do tabloide "Lampião", órgão que, conforme o apurado regularmente e com respaldo no Parecer Censório emitido pelo Serviço de Censura e Diversões Públicas/SR/RJ, se dedica exclusivamente à apologia do homosexualismo, queremos aqui esclarecer que a finalidade deste Inquérito é, não só enviar ao Estado-juiz a pretensão punitiva dos indiciados, como, por outro lado, considerando que [...] [a legislação] não tolera as publicações e exteriorizações contrárias à moral e aos bons costumes, solicitar enérgicas providências para a suspensão definitiva do jornal em questão (Brasil, 1979e).

Deixa-se claro, assim, que o objetivo não era apenas punir os indiciados, mas cassar o funcionamento do jornal definitivamente, evidenciando uma estratégia mais ampla da ditadura de minimizar o fortalecimento das oposições no contexto da abertura mediante a cassação de seus órgãos de comunicação e de denúncia.

Prosseguia o relatório, seguido de assinatura do Dr. Motta e datado de 20 de setembro de 1979, afirmando que, após analisar a situação financeira bastante pobre do jornal, só poderia consistir em uma iniciativa de ataque ao regime e aos valores morais:

Para atender a tais providências solicitamos, através de ofício, a apresentação da respectiva escrituração da firma, no que fomos atendidos, com a qual pudemos provar ser uma empresa sem lucro de qualquer espécie, com a ínfima tiragem mensal de cerca de 4.000 exemplares, inclusive não contando com anúncios ou mensagens comerciais em suas páginas, fato este que nos leva a pressupor, e neste caso a presunção é válida, de que o tablóide LAMPIÃO DE ESQUINA [sic] tem como finalidade última uma velada mensagem desagregadora, com vistas à destruição de nossa cultura, interesses, sentimentos familiares, costumes e aspirações comuns. Ocorre-nos pensar no emprego de técnicas sub-reptícias de aliciamento, no propósito nefasto de enfraquecer os valores humanos, então presa fácil a desígnios inconfessáveis, ou seja, à deterioração da autoridade e da disciplina que cria condições pessoais que levam a juventude à aceitação de ideologias estranhas às nossas concepções (BRASIL, 1979e, grifos no original).

Mas os documentos que revelavam, sem rodeios, as intenções ocultas por parte do regime de fechar o jornal, não eram plenamente conhecidos, pois o processo administrativo mencionado corria em caráter de confidencialidade. Mesmo assim, alguns sinais já indicavam que a medida arbitrária derivava de uma orientação do Centro de Informações do Exército para exterminar a Imprensa Nanica.

O documento que sustentava esta versão, publicado no jornal Estado de São Paulo, no dia 18 de abril de 1979, revelava um plano para a eliminação da imprensa nanica por meio de pressões econômicas, "sem atingir a liberdade de pensamento". Um dos itens do referido documento pontuava que "dentro da imprensa nanica [vinha] crescendo ultimamente a chamada 'imprensa gay', que se disp[unha] a defender as atitudes homossexuais como atos normais da vida humana" (Lampião da Esquina, 2(19),1979:2). Percebe-se, assim, que se tratou de uma estratégia deliberada da repressão para conseguir coibir a circulação dos jornais menores sem, contudo, assumir o ônus que a censura aberta e declarada provocaria nos anos de abertura.

Aparentemente pego de surpresa, por se tratar de um inquérito legado por seu antecessor, o Ministro da Justiça Petrônio Portella determinou que, ainda no dia 11, o DPF lhe entregasse um relatório completo sobre o inquérito.

A ordem foi cumprida e o Ministro divulgou, no fim da tarde desse mesmo dia, uma nota com a explicação do diretor do DPF, Moacir Coelho: com essa solicitação de livros contábeis e balancetes, pretendia a polícia provar que a editora "não tinha condições de sobreviver como 
empresa" (Lampião da Esquina, 2(15), 1979:5). Ao invés de abafar o caso, tal resposta gerou ainda mais indignação e solidariedade em prol da continuidade do Lampião, por confirmar os propósitos ocultos de fechar o jornal.

Na nota divulgada pelo jornal, encontra-se uma resposta contundente à alegação do coronel Moacir Coelho. O Lampião afirmou, na ocasião: "não cabe à Polícia Federal - e este é o ponto mais central da questão - verificar se uma empresa tem ou não condições de se manter". A nota pontuava que, por não visar lucro, a editora do Lampião não apresenta problemas financeiros, sendo que o dinheiro arrecadado com a venda de um exemplar era consumido na edição do número seguinte. Por fim, os editores jogaram uma questão incômoda no colo do governo:

como um jornal de minorias, assumindo uma posição descomprometida em relação a todas as propostas ora em discussão no País, vem se tornando, nestes momentos de anunciada abertura, vítimas de constantes arbitrariedades desse tipo: seria a necessidade de eleger bodes expiatórios? Se o DPF acha que nós não temos condições de nos manter, que responda a essa pergunta: quem nos financia? O jornal está no n. 14, e nunca atrasou na sua chegada às bancas (Lampião da Esquina, 2(15), 1979:5).

Assim, em meio à tensão escancarada, somente após intimação pelo órgão competente é que, em 16 de agosto de 1979, a editora apresentou ao Delegado de Polícia Federal os balancetes extraídos dos livros contábeis da empresa responsável pelo Lampião. Conforme consta no documento protocolado pelo contador Josias Barbosa Santana, o balanço patrimonial do primeiro ano de funcionamento do jornal acumulou, até 31 de dezembro de 1978, o prejuízo de 7.193,75 unidades monetárias da época. Já o balancete de verificação, assinado pelo mesmo contador em 16 de agosto de 1979, relativo ao primeiro semestre até 31 de julho de 1979, mostrava já um jornal em razoável saúde financeira, com um total acumulado de 648.323, 25, revertendo o prejuízo do ano anterior já no primeiro semestre de 1979 (Brasil, 1979f).

Além disso, um mês antes, provavelmente para conferência da veracidade das informações prestadas, o Delegado José da Silva Motta solicitou diligência registrada no Relatório de Missão n. 036/79-Cart/DOPS para verificar, junto à distribuidora de jornais e revistas, a quantidade do referido jornal distribuído ao público em 1979. Nesse informe, de 6 de julho, constam 4250 exemplares em janeiro, 4300 em fevereiro, 4400 em março e 4000 de março até julho(Brasil, 1979g).

Na entrevista feita com Ney Matogrosso, publicada em dezembro de 1979, o cantor inverteu a posição de entrevistado e perguntou aos jornalistas do Lampião a quantas andava o processo contra o tabloide. Aguinaldo Silva respondeu, ironicamente, que "o motivo [era] sempre o mesmo: 'ofensa à moral e aos bons costumes'. Ou seja: os 'bons costumes' dos Lutfalla, dos Abdalla e dos Grupos Lume da vida estão ameaçados porque há pessoas, como as do LAMPIÃO, que preferem fazer jornal, em vez de dar golpes na praça” (Lampião da Esquina, 1(11), 1979:7).

A despeito de todos os esforços para encontrar alguma irregularidade, nada foi encontrado de comprometedor do ponto de vista contábil, já que o jornal cativou um público expressivo e, se é verdade que não gerou muito lucro - o que sequer era seu objetivo -, ele conseguiu uma vendagem $e$ anúncios suficientes para manutenção da circulação mensal por 3 anos ininterruptamente.

Isso atesta, cabalmente, que a exigência da ditadura não era uma preocupação com fundamento, mas mera tentativa de cercear a circulação do jornal por meio de algum expediente fiscal que não expusesse a repressão em estado bruto e gerasse ainda mais resistência e oposição ao regime.

\section{Um Lampião iluminado pela solidariedade}

Diante do embate com risco de fechamento do Lampião, todos os grandes jornais da época noticiaram com destaque o fato, reproduzindo a nota do Lampião. Jornais como OGlobo; Tribunal da Imprensa; Última Hora; Estado de São Paulo; Folha de São Paulo, dentre outros expuseram o documento em suas páginas. 
Ao contrário do que aconteceu com Celso Curi, que foi vítima de um processo judicial com os mesmos fundamentos sem receber suporte expressivo para resistir às pressões que vinha sofrendo, a caça ao Lampião despertou solidariedade e apoio de diversos setores. Apesar do curto intervalo que separou os dois casos, os tempos já eram outros e, entre os inquéritos de Curi e Lampião, houve uma diferença fundamental: a emergência de uma novidade chamada movimento homossexual, que parecia ainda uma utopia irrealizável em 1976 e que já dava seus primeiros sinais de emergência com o grupo Somos a partir de maio de 1978 em São Paulo.

A Comissão Permanente de Luta pela Liberdade de Expressão, que congregava 25 entidades no Rio de Janeiro, divulgou nota com o seguinte teor:

No caso particular do Em Tempo e do LAMPIÃO, aguardamos do Poder Executivo a apuração da responsabilidade nas diferentes ações que vêm restringindo o trabalho e o exercício profissional dos que buscam, nestes jornais, dar a sua contribuição à construção de uma sociedade democrática (Lampião da Esquina, 2(15), 1979:5).

Além disso, foi organizado um Comitê de Defesa do Jornal Lampião, composto por ativistas do Grupo Somos, jornalistas, intelectuais e leitores do periódico, com o objetivo de desencadear uma campanha de solidariedade na opinião pública. Nos termos anunciados no texto de lançamento do Comitê, o objetivo era colher "assinaturas de apoio a este jornal, e mobilizando entidades nacionais e internacionais para protestarem contra as arbitrariedades que vimos sofrendo" conforme divulgado nas páginas do próprio jornal (Lampião da Esquina, 2(15), 1979:5).

Um manifesto em defesa da imprensa alternativa foi também organizado, contando com a rápida adesão de amplo setor da intelligentsia brasileira, tais como Plínio Marcos, Ivan Lins, Antonio Candido, José Arthur Giannotti, Fernando Henrique Cardoso, Ruth Cardoso, Cândido Procópio, Nicete Bruno, José Celso Martinez Corrêa, Fernando Morais, Eduardo Suplicy, entre outros. Além disso, jornais tais como Versus, Convergência Socialista e Movimento, bem como entidades de trabalhadores como a APEOESP, Sindicato dos Jornalistas de SP e Sindicato dos Bancários de SP, também saíram em defesa do jornal. A coleta de novas assinaturas foi interrompida porque logo após o início da campanha, houve o arquivamento do inquérito. De qualquer modo, este manifesto do campo democrático afirmava veementemente seu apoio ao Lampião:

nós abaixo assinados, entendemos estes atos oficiais [do inquérito e do pedido de apresentação de livros contábeis] como uma tentativa de castrar o diálogo sobre os setores oprimidos 'minoritários' que se faz necessário e urgente dentro de nosso país, bem como repudiamos todas as atividades de coerção e repressão ao direito de existência e manifestação da imprensa alternativa (Lampião da Esquina, 2(15), 1979:5).

A repercussão do caso mobilizou, ainda, uma rede internacional de ativismo gay ${ }^{3}$ bastante surpreendente. O diálogo com entidades estrangeiras que o jornal mostrava nas traduções publicadas e os contatos de militantes de outros países cultivaram uma relação de cumplicidade significativa. Uma série de cartas e de abaixo-assinados, oriundas dos mais diferentes países e escritas em diversos idiomas, foi enviada ao Ministro da Justiça Armando Falcão e, posteriormente, ao Petrônio Portella, durante a tramitação do inquérito. Exemplos de entidades signatárias foram National Gay Federation (Dublin), AHA (Berlim), Centre Du Christ Liberateur (Paris), AG Lesben \& Schwule (Hamburgo), FUORI (Itália), Gay Activist Alliance (Inglaterra), National Gay Task Force (EUA), dentre outras dezenas de agrupamentos.

Todas elas, com uma redação mais ou menos igual e quase sempre em inglês, expressavam a "preocupação com a arbitrariedade e a severidade dessas medidas", requerendo ao Ministro que "exer[cesse] sua influência em nome dos direitos humanos e dos direitos civis no seu país". Algumas das cartas eram ainda mais duras e afirmavam:

\footnotetext{
3 Utiliza-se aqui o termo "gay" por ser o mais reivindicado à época pelo então chamado movimento homossexual ou gay internacional. No Brasil, apenas a partir dos anos 2000 é que será usada a sigla LGBT+, mais inclusiva e representativa da diversidade de identidades que compõem a comunidade.
} 
como ministro da Justiça, você certamente não gostaria de ser colocado ao lado de Adolf Hitler ou Anita Bryant, os quais, de uma maneira monstruosa, foram culpados pela difamação e assassinato de muitos homossexuais inocentes nesse século (Brasil, 1979h).

\section{"Somos todos inocentes": o arquivamento do inquérito contra o Lampião}

Diante da resistência implacável do Lampião e da expressiva rede de solidariedade articulada, passado mais de um ano de tramitação lenta e angustiante, o inquérito foi arquivado por determinação judicial.

Mas até mesmo para obter a vitória, tão difícil e sofrida, foi necessário que a defesa aliviasse a homossexualidade dos editores e da linha política do jornal para não influenciar negativamente o procurador ou o juiz. A "timidez" imposta aos homossexuais, até mesmo na hora de sua defesa, é uma das perversidades que a homofobia institucionalizada da ditadura acentuou ${ }^{4}$.

Em seu parecer, transcrito no Lampião, o Procurador da República Dr. Sérgio Ribeiro da Costa analisou o conceito de moral pública e bons costumes de que trata a lei de Imprensa. Segundo o procurador,

filosoficamente moral e bons costumes se confundem, porque a moral é a parte da filosofia que trata dos costumes ou dos deveres do homem. Já a moral pública tem um conceito absoluto, vale dizer, é a conclusão moral que o público tira de uma determinada conduta. Simplificando, há fatos que pelo seu conteúdo ofendem a moral e alguns. A Lei visa, tão-somente, punir os fatos que ofendem a moral de todos - a moral absoluta - e não a moral de alguns - a moral relativa. No caso em exame, a publicação inquinada de ofensiva à moral pública pode ofender a moral de alguém, mas não de todos. Portanto, é relativo e não absoluto o conceito de moral daquele que condena essas publicações. Com efeito, as matérias publicadas no referido jornal referem-se a teses homossexuais, poesias ligadas a temas homossexuais, notícias ligadas ao mundo da homossexualidade, porém todas elas escritas num vocabulário que não atenta à moral pública (Lampião da Esquina, 2(18), 1979:2).

O procurador acrescenta, ainda, que inúmeros poemas da literatura universal estavam ligados a "problemas homossexuais", como de Miguel Ângelo e Shakespeare. Tal parecer foi acolhido pelo Juiz da $4^{\text {a }}$ Vara Federal do Rio de Janeiro, Dr. Ariosto de Rezende Rocha.

Nessa edição de novembro de 1979, então, o Lampião celebrou a tão esperada vitória no artigo de abertura assinado por Aguinaldo Silva e intitulado "Somos todos inocentes":

Foram doze meses de choro, ranger de dentes e defecções, desde aquele dia, no mês de agosto de 1978, em que chegou uma primeira intimação, em nome de Francisco Bittencourt; tratavase, como se pode ver - agora que tudo terminou e nós, finalmente, temos acesso ao inquérito de uma firme determinação do Departamento de Polícia Federal de não apenas fechar o LAMPIÃO como também punir os responsáveis por ele (Lampião da Esquina, 2(18), 1979:2).

\section{"Eu atribuo o fim do jornal ao meu cansaço": "diário oficial do ativismo guei"?}

A despeito dos apoios e da vitória na batalha judicial, a crise do jornal foi se aprofundando, tanto pelos efeitos da perseguição institucionalizada da ditadura ${ }^{5}$ - que se arrefeceu oficialmente após o arquivamento do inquérito, como pela violência crua materializada nas bombas jogadas em bancas que comercializassem os jornais alternativos ${ }^{6}$. Alguns problemas enfrentados pelo Lampião

\footnotetext{
4 MacRae destacou este fato ao afirmar que "até durante os inquéritos policiais sobre o Lampião, a defesa achou prudente enfatizar ao máximo a categoria de 'jornal das minorias', tentando minimizar seu aspecto homossexual" (1990:171).

5 MacRae afirma que a perseguição ao Lampião era um capítulo da repressão mais ampla exercida contra os homossexuais: "O próprio documento do CIEx mencionava nominalmente o Lampião como um jornal a ser vigiado. A única forma oficialmente aceitável de abordar o assunto parecia ser aquela da imprensa sensacionalista do tipo Notícias Populares, ou deturpadora como a Manchete" (1990:170).

6 Trevisan destaca que as explosões de bancas vinham acompanhadas de panfletos anônimos exigindo que jornais alternativos, como o Lampião, deixassem de ser vendidos. Essas "bombas foram vagamente atribuídas, pelo governo, a comandos paramilitares. Mas nunca se instaurou nenhum inquérito" (Trevisan, 2007:346).
} 
eram, em certa medida, parte das dificuldades presentes em todos os demais veículos da imprensa alternativa. Além disso, havia também uma crise de identidade específica que começava a emergir depois de tanto tempo com uma série de atritos com o movimento homossexual, levando os editores a se questionarem se ainda e em que medida estavam conseguindo levar adiante o propósito original do jornal de inovar as formas de pensar as questões das minorias ${ }^{7}$.

Começaram a ganhar mais força, paralelamente às demais questões, as críticas dos grupos homossexuais que acusavam o jornal de um distanciamento das lutas concretas e do ativismo gay. Em novembro de 1980, os grupos Auê/RJ, Somos/RJ, Grupo Opção à Liberdade Sexual (Gols)/Santo André/SP, Bando de Cá/Niterói/RJ, Grupo Gay da Bahia (GGB)/Salvador/BA e Grupo de Ação Lésbica Feminista (GALF)/São Paulo/SP entregaram ao jornal um documento reclamando de seu distanciamento e das mudanças que estavam acontecendo (Lampião da Esquina, 3(31), 1980:12).

A cisão no interior do movimento homossexual também colocou em questão a neutralidade do Lampião na disputa de concepções de ativismo. O Jornal deixou de ser unanimidade e passou a ser constantemente questionado em relação a suas escolhas editoriais e posições políticas ${ }^{8}$. $\mathrm{O}$ texto "Teses para a libertação homossexual II", da Fração Homossexual da Convergência Socialista, escrito em setembro de 1980, acusava o Lampião de arvorar-se na condição de "porta-voz do movimento homossexual" e, assim, manter uma posição anárquica e anti-esquerda". Desde tal entendimento, o jornal bancava "um papel de frear o crescimento do $\mathrm{MH}$ e sua organização política", foi duramente respondido por membros do conselho editorial como Francisco Bittencourt (Lampião da Esquina, 3(31), 1980:13) e Darcy Penteado (Lampião da Esquina, 3(31), 1980:14).

$\mathrm{Na}$ edição de agosto de 1980, por exemplo, o Lampião reagiu à enxurrada de críticas e questionamentos. Aguinaldo Silva, que cada vez mais detinha o controle do jornal, publicou um texto intitulado "Uma cachoeira de grupos gueis", em que demarcava claramente uma distância com o movimento homossexual e afirmava que "não [era] possível, para nós, transformar o LAMPIÃO, uma espécie de "diário oficial do ativismo guei", pois isso restringiria o alcance e as vendas do jornal (Lampião da Esquina, 3(27), 1980:4).

Espremido entre o que se consideravam ser os interesses inconciliáveis do mercado, de um lado, e os do ativismo gay, de outro, o jornal não conseguia contemplar, satisfatoriamente, nenhum dos dois públicos, pois o primeiro dispunha de outras revistas eróticas e pornográficas em circulação, enquanto os segundos já haviam se afastado. Dividido entre consumismo e ativismo, o jornal ficou sem espaço para continuar.

Ao lado de todas essas determinantes externas, agravaram-se determinados problemas internos quanto ao convívio que estava cada vez mais desgastado. O esgarçamento das relações provocados por um racha editorial também convergiu para provocar o fim do jornal. Duas das personagens mais influentes e ativas no Conselho, Aguinaldo Silva, no Rio, e Trevisan, em São Paulo, viram suas diferenças ficarem cada vez mais acentuadas diante da crise do Lampião.

Segundo Aguinaldo, "havia um grupo que achava que o jornal devia ser panfletário e não se preocupar em ter uma linguagem jornalística. E isso era um problema, porque um jornal que fosse só ativista acabava limitado. Nas reuniões de pauta, sempre havia discussões árduas em torno dessa questão" (Péret, 2011:58). A politização da atuação do jornal não era uma questão nova, mas uma divergência constitutiva do próprio Lampião e sempre foi administrada dentro de limites que permitiram a continuidade do projeto com uma pluralidade de posições.

Por sua vez, Trevisan, que tinha um perfil mais assumidamente militante do movimento homossexual, acusava o grupo carioca de desvirtuar o projeto original do jornal, que "começou a tender para um certo sensacionalismo, com chamadas sensacionalistas, para chamar atenção de um público que não estava tão interessado assim" (Lampião da Esquina, 2016, min. 68). A ida constante ao Rio de Janeiro para as reunióes era desgastante e cara, além de que Trevisan não

\footnotetext{
7 Ver, por exemplo, o editorial da edição n. 28, de setembro de 1980, intitulado "Nós ainda estamos aqui".

8 Trevisan (2007:361) afirmou que o jornal "acabou radicalizando infantilmente seu repúdio ao ativismo gay. Certos setores do jornal mergulharam num vago populismo, brandindo descabidamente o travesti em contrapartida ao gueimacho, o que acabou lhe dando um aspecto quase tão sensacionalista quanto os jornais da imprensa marrom", ocasionando a descaracterização das intenções do projeto original e uma diminuição nas vendas.
} 
tinha apoio suficiente dos demais membros em São Paulo para assumir a condução do jornal. Assim, ele atribuiu a si mesmo a iniciativa de ter ido ao Rio exigir que o jornal acabasse, por ter cumprido sua função e ser hora "de passar para outra" (Lampião da Esquina, 2016, min. 72).

A versão de Aguinaldo, presente em documentário sobre o jornal lançado em 2016, é no sentido de que ele próprio decidira pelo fim do jornal e, ao apresentar sua renúncia como editor, ninguém teria se voluntariado para substituí-lo nesta tarefa: "Eu atribuo o fim do jornal ao meu cansaço. Quando eu saí do jornal, eu disse: a partir de hoje eu não edito mais, vocês escolham outra pessoa... e ninguém se apresentou para editar, o jornal acabou por isso" (Lampião da Esquina, 2016, min. 70).

Além disso, as grandes diferenças de interesses e abordagens entre a imprensa "nanica" e a tradicional, também pejorativamente designada "marrom", foi diminuindo com o passar do tempo, a afirmação dos movimentos identitários. Os veículos da imprensa alternativa provocaram mudanças importantes nos meios de comunicação hegemônicos, pautando temas que eram ignorados ou desprezados pela grande imprensa. Neste sentido, na opinião de Trevisan, questões de gênero, sexualidade e raça deixaram de ser exclusivas dos órgãos alternativos, o que contribuiu para o esvaziamento de alguns destes jornais: "De repente, a Folha começou a ter uma coluna feminista, começou a ter uma coluna sobre racismo, ecologia. Os temas típicos do Lampião foram cooptados pela grande imprensa" (Lampião da Esquina, 2016, min. 71)

Com efeito, o jornal, que havia surgido em um momento de efervescência da abertura, beneficiou-se de certo ineditismo da proposta e do retorno de exilados com ideias novas trazidas do estrangeiro. Essas novidades comportamentais e artísticas que eclodiram a partir do verão de 1980 foram atingidas em cheio pela crise econômica e inflacionária de 1981, levando à recessão de 1982. Com menos dinheiro e interesse cada vez menor, as vendas do jornal caíram, o que acentuou a sensação de esgotamento do projeto.

Já para Glauco, colaborador assíduo do jornal, a transitoriedade era uma característica inescapável deste tipo de publicação inovadora e vanguardista, pois "não era um jornal para criar hábito, não era o caso do Lampião" (Lampião da Esquina, 2016, min. 70). Outro fator lembrado no documentário sobre o jornal foi a acusação de abuso de menor que pesava contra Antônio Chrysóstomo, preocupando alguns lampiônicos que houvesse uma associação entre pedofilia $e$ homossexualidade (Lampião da Esquina, 2016, min. 77).

Em suma, diante dessas versões diferentes e até conflitantes entre si, que não deixam de refletir as divisões e tensões internas existentes entre os editores, pode-se concluir que não houve uma única causa capaz de explicar o apagamento do Lampião da Esquina.

O contexto repressivo da ditadura, que perseguia e ameaçava abertamente jornalistas, a perspectiva hetero-militar que foi institucionalizada e alçada à política de Estado nesse período, os atentados paramilitares com bombas colocadas nas bancas em que o Lampião era vendido, as divergências quanto à identidade da publicação em um jornalismo em franca transformação, o agravamento da crise dos grupos ativistas pioneiros e também destes em relação ao jornal, as dificuldades financeiras e a devassa contábil, além de outros problemas de ordem pessoal dos conselheiros, foram todos fatores que concorreram para que a mais impactante experiência de imprensa gay (Péret, 2011) chegasse a seu final, contribuindo também com o declínio da primeira onda do movimento homossexual brasileiro.

Desse modo, o que buscamos demonstrar é que, em meio a toda essa complexidade de variáveis, despontaram com grande relevo as ações diretas e indiretas perpetradas pela ditadura brasileira com o objetivo expresso e declarado de acabar com o Lampião. Pode-se dizer que estas iniciativas foram, inclusive, tanto um capítulo específico das políticas sexuais do regime autoritário quanto da repressão à imprensa e da censura instituídos a partir do golpe de 1964 .

No contexto da lenta e controlada redemocratização em curso naquele momento, acentuouse uma preocupação em compensar a liberalização política com o endurecimento moral que impactou mais intensamente os meios que questionavam padrões sociais de gênero, formas tradicionais de família e comportamentos sexuais considerados "normais" (Quinalha, 2017).

Conforme analisado neste artigo, tais ações ditatoriais contra o Lampião, que foram fundamentais para o fechamento do jornal, concretizaram-se em diversas dimensões. Primeiro, 
restringindo a liberdade de manifestação de ideias e de pensamento por meio da censura e da perseguição de jornalistas, o que afetava o processo criativo dos colaboradores do jornal. Segundo, impedindo a livre circulação dos exemplares nas bancas de jornais e a distribuição em todo território nacional. Terceiro, produzindo dossiês e informações para provocar órgãos acusadores a processar os editores, com todos os ônus burocráticos e econômicos que isso implica, com efeito dissuasivo evidente. Quarto, por meio de uma devassa contábil para fechar o jornal com um pretexto mais "técnico" ou "neutro" e menos "político". Isso sem falar na ameaça mais ampla que pairava sobre a sociedade como um todo.

Mesmo diante de tais medidas, o jornal logrou uma existência de três anos, um tempo de vida significativo. Essa longevidade só foi possível por conta das articulações e resistências forjadas no interior do incipiente movimento homossexual e dos demais grupos que se engajavam nas lutas pelas liberdades democráticas no contexto da transição. Aproveitaram-se das poucas brechas institucionais e dos escassos canais de comunicação disponíveis para veicular as denúncias e cobrar o respeito à livre expressão, como demonstra a campanha de solidariedade ao Lampião dentro e fora do Brasil.

As mesmas medidas autoritárias que colocavam em risco permanente a continuidade da publicação, paradoxalmente, tiveram por efeito colateral e imprevisto o fortalecimento das redes de resistência, mas as crises internas do próprio jornal, potencializadas pela repressão ditatorial ainda subsistente, acabaram levando ao encerramento do periódico. Mas seu fim legou profundas marcas e influências para os debates em torno das questões LGBT + no Brasil, visíveis até os dias de hoje.

\section{Referências bibliográficas}

GREEN, James N.; QUINALHA, Renan (org.). Ditadura e homossexualidades: repressão, resistência e a busca da verdade. São Carlos, EdUFSCar, 2014.

KUCINSKI, Bernardo. Jornalistas e revolucionários: nos tempos da imprensa alternativa. São Paulo, Edusp, 2001.

LAMPIÃO da Esquina. Direção de Livia Perez. São Paulo, Doctela, 2016 (82 min).

LIMA, Baiardo de Andrade. Um candidato fala mais alto. Lampião da Esquina, n. 6, novembro de 1978, p. 4.

MACRAE, Edward. A construção da igualdade: identidade sexual e política no Brasil da "abertura". Campinas, Editora da Unicamp, 1990.

PÉRET, Flávia. Imprensa gay no Brasil. São Paulo, Publifolha, 2011.

QUINALHA, Renan. Contra a moral e os bons costumes: as políticas sexuais da ditadura brasileira (1964 1988). Tese (Doutorado em Relações Internacionais), USP, São Paulo, 2017.

TREVISAN, João Silvério. Devassos no paraíso: a homossexualidade no Brasil, da colônia à atualidade. São Paulo, Record, 2007.

\section{Fontes}

BRASIL. Arquivo Nacional (Rio de Janeiro). Fundo Centro de Informações do Exército. Informação n. 483 S/102-A11/CIE. Brasília, 6/4/1978a.

BRASIL. Arquivo Nacional (Rio de Janeiro). Fundo Ministério da Justiça. Informação n. 895/78. Brasília, 28/11/1978b.

BRASIL. Arquivo Nacional (Rio de Janeiro). Fundo do Sistema Nacional de Informações. Termo de declarações perante o DOPS/SR/DPF/RJ. Rio de Janeiro, 24/11/1978c.

BRASIL. Arquivo Nacional (Rio de Janeiro). Fundo do Serviço de Censura de Diversões Públicas. Parecer n. 3348 no Memorando n. 241/78 CART/DOPS. Rio de Janeiro, 22/11/1978d.

BRASIL. Arquivo Nacional (Rio de Janeiro). Fundo do Serviço Nacional de Informações. Relatório. Rio de Janeiro, 9/8/1978e.

BRASIL. Arquivo Público (Rio de Janeiro). Fundo do Serviço Nacional de Informações. Portaria (sem número) da Delegacia de Ordem Política e Social/SR/DPF/RJ. Rio de Janeiro, 21/8/1978f. 
BRASIL. Arquivo Nacional (Rio de Janeiro). Fundo do Serviço Nacional de Informações. Apreciação Especial n.001/19/AC/79. Brasília, 2/1/1979a.

BRASIL. Arquivo Nacional (Rio de Janeiro). Fundo do Serviço Nacional de Informações. Ofício 033/79DPF/SR/RJ CART/DOPS. Rio de Janeiro, 26/1/1979b.

BRASIL. Arquivo Nacional (Rio de Janeiro). Fundo do Serviço Nacional de Informações. Ofício n. 194/79Cart/DOPS/SR/DPF/RJ. Rio de Janeiro, 3/7/1979c.

BRASIL. Arquivo Nacional (Rio de Janeiro). Fundo do Serviço Nacional de Informações. Telegrama do Sindicato dos Jornalistas do Município do Rio de Janeiro. Rio de Janeiro, 11/7/1979d.

BRASIL, Arquivo Nacional (Rio de Janeiro). Fundo do Serviço Nacional de Informações. Relatório (sem número). Rio de Janeiro, 20/9/1979e.

BRASIL. Arquivo Nacional (Rio de Janeiro). Fundo do Sistema Nacional de Informações. Balancete Patrimonial. Rio de Janeiro, 16/8/1979f.

BRASIL. Arquivo Nacional (Rio de Janeiro). Fundo do Serviço Nacional de Informações. Relatório de Missão n. 036/79-Cart/DOPS. Rio de Janeiro, 6/7/1979g.

BRASIL. Arquivo Nacional (Rio de Janeiro). Fundo do Sistema Nacional de Informações. Cartas de solidariedade internacional. Sem local, 1979h.

BRASIL. Arquivo Nacional (Rio de Janeiro). Fundo do Centro de Informações de Segurança da Aeronáutica. Informação n. 0854/CISA-RJ. Rio de Janeiro, 2/1/1980a.

BRASIL. Arquivo Nacional (Rio de Janeiro). Fundo do Serviço Nacional de Informações. Informação n. 051/19/AC/80. Sem local, 11/3/1980b.

BRASIL. Arquivo Nacional (Rio de Janeiro). Fundo do Serviço Nacional de Informações. Informação n. 202/04/DSI/MJ/346778. Sem local, 26/6/1981.

Lampião da Esquina. Rio de Janeiro, 1978 - 1981. Diversas edições [https://www.grupodignidade.org.br/projetos/lampiao-da-esquina/ - acesso em: 10/01/2019]. 